\title{
The positive impact over time of Master's level education on nurses' utilization of nursing research-related tasks in clinical practice - A longitudinal cohort study
}

\author{
Connie Berthelsen*, Bente Martinsen, Marianne Vamosi \\ Research Unit of Nursing and Healthcare, Institute of Health, Nursing, Aarhus University, Denmark
}

Received: November 7, 2019

DOI: $10.5430 /$ jnep.v10n4p1
Accepted: November 27, 2019 Online Published: December 10, 2019

URL: https://doi.org/10.5430/jnep.v10n4p1

\begin{abstract}
Objective: To describe and compare the development of Master of Science in Nursing graduates' utilization and improvement of nursing research-related tasks and knowledge in daily clinical practice, six months and twelve months after graduation.

Methods: A longitudinal cohort study of 65 Master of Science in Nursing (MSN) graduates from a Danish university was conducted from 2016 to 2017. Data were collected six and twelve months after graduation using a purposive-constructed questionnaire based on four validated questionnaires. Data were analyzed using descriptive statistics and STATA software (12.0). Results: The overall results of the longitudinal cohort study showed a positive impact 12 months after graduation on the MSN graduates' development and improvement of their utilization of nursing research-related tasks and knowledge in clinical practice. The results also showed a development in the MSN graduates' employment in academic positions, as well as an increase in the number of hours per week spent on nursing research-related tasks.

Conclusions: Providing nurses with Master's level knowledge and skills can make a difference for them in clinical practice. However, knowledge is still needed on how the MSN qualification can have an impact on patient care: Future research must focus on practical observations of how the Msn graduates use their academic knowledge and skills to improve patient care, using specific outcomes and observable criteria.
\end{abstract}

Key Words: Clinical practice, Longitudinal study, Master of Science in Nursing, Nurses, Research collaboration, Research utilization

\section{INTRODUCTION}

The healthcare system is continuously increasing its demands for evidence-based practice to improve patient care. ${ }^{[1]} \mathrm{Nu}$ merous studies show that research-based knowledge is infrequently used in clinical practice, ${ }^{[2-4]}$ which may have undesirable consequences for patient care and treatment. ${ }^{[5,6]}$ The reasons for the lack of research-based knowledge in clinical practice is due to several barriers to research utilization, such as lack of time, ${ }^{[7,8]}$ lack of academic role models, ${ }^{[3]}$ lack of support from the organization, ${ }^{[1,9]}$ and lack of support from colleagues. ${ }^{[10]}$ Studies also show how lack of knowledge is a considerable barrier to registered nurses working in basic hospital positions. ${ }^{[10,11]}$ In order to improve and enhance knowledge about research, as well as research-based

\footnotetext{
* Correspondence: Connie Berthelsen; Email: cb@ph.au.dk; Address: Research Unit of Nursing and Healthcare, Institute of Health, Nursing, Aarhus University, Campus Emdrup, Tuborgvej 164, 2400 Copenhagen, Denmark. 
knowledge used in clinical practice, nurses are encouraged to undertake postgraduate education to improve their educational, management, and scientific knowledge. ${ }^{[12,13]}$ MSN graduates view their postgraduate education as an important part of being in clinical practice ${ }^{[12]}$ and the direct benefits of postgraduate nursing education to improve nurses' competencies are well established. ${ }^{[13]}$

The value of postgraduate education for nurses is increasingly recognized and there is growing evidence that nurses who undertake further academic education are more likely to have greater academic knowledge and competencies, ${ }^{[14]}$ which may lead to greater opportunities for nurses to engage in nursing research in clinical practice. The requisition of advanced professional and research capabilities, such as advanced academic skills and subject knowledge used to perform nursing research-related tasks ${ }^{[15]}$ are important factors for nurses completing a higher education degree. ${ }^{[12]}$ Nursing research-related tasks are related to the specific tasks of initiation and preparation of the research project, tasks during the research project, finishing the research project, and interacting with students. ${ }^{[16]}$ However, the tasks also concern concrete actions related to research, such as the use of methods and analysis, literature search, ability to read, appraise and disseminate research, and obtaining funding, but they also see the tasks as project related. ${ }^{[17]}$

The literature also show how completing a MSN eductation kan have positive professional and personal gains for nurses. ${ }^{[13]}$ The professional gains for the MSN graduates are related to enhancing academic knowledge and integrating the new knowledge into clinical practice, applying theory to practice, and developing competencies in writing and appraising research. ${ }^{[13,18]}$ The personal gains for nurses completing an MSN degree include increased confidence and self-esteem, analytical thinking and decision-making, and evidence-based practice skills ${ }^{[13,14,18,19]}$ as well as an improved cognitive function [18] and a higher level of critical thinking which has shown to be a significant predictor of nurses' sense of competence. ${ }^{[4,19]}$

A Most research in nursing has been performed at universities, but owing to an increasing number of academic positions in clinical practice, experienced nursing researchers are now more frequently employed in the healthcare system. ${ }^{[20]}$ Although the nurses with MSN degrees have attained the scientific and academic competencies and knowledge needed to support evidence-based practice, new knowledge is needed on how the MSN graduates actually use, include and develop their academic skills in their clinical practice positions. We therefore conducted a longitudinal cohort study to describe and compare the development of MSN graduates' utiliza- tion and improvement of nursing research-related tasks and knowledge in daily clinical practice, six months and twelve months after graduation.

\section{METHODS}

\subsection{Design}

A longitudinal cohort study of MSN graduates from a Danish university was conducted. The longitudinal design was chosen due to its strength of examining whether changes have occurred over time, ${ }^{[21]}$ which was why it was appropriate for our study to compare the MSN graduates' utilization of nursing research-related tasks at six months and twelve months after graduation.

\subsection{Participants}

Two classes of nurses graduating from an MSN programme at a Danish university in the year 2016-2017 were invited to participate in our longitudinal cohort study. The nurses ( $\mathrm{N}$ =112) were contacted one month before graduation via the university's internal mail system and were informed about the study and their ethical and legal rights as participants. The nurses were requested to send an email to the first author within 14 days if they wished to participate. A gentle reminder was sent after 14 days to those who had not replied.

\subsection{The questionnaire}

The questionnaire used for data collection in this longitudinal cohort study was constructed by the authors for a crosssectional study concerning MSN students' expectations of participating in nursing research-related tasks in daily clinical practice after completing their education. ${ }^{[22]}$ The questionnaire was constructed from six validated and published questionnaires ${ }^{[12,17,23-26]}$ and finally validated through construct and content validity by the three authors, and face validity by MSN students enrolled in the current programme. ${ }^{[22]}$ The specific descriptions and psychometric values of the six questionnaires are described in detail in the referred paper. ${ }^{[22]}$

\section{The alterations creating the final questionnaire}

The questionnaire went through minor alterations before being included in this current study, since it was constructed for MSN students' expectations to participate in research-related tasks, ${ }^{[22]}$ and was now to be used for the MSN graduates' experiences of utilization of nursing research-related tasks in daily clinical practice. After much consideration, the three authors decided that the themes covering the nurses' expectations regarding their opportunities for engaging in nursing research-related tasks, ${ }^{[23,25]}$ their motivation ${ }^{[17]}$ and research collaboration $^{[24]}$ should be omitted, since these were of minor relevance to the study.

The final questionnaire for this study consisted of five themes: 
1) the demographic data on the participating MSN graduates, consisting of age, number of years qualified as a nurse, number of years of experience in clinical practice, professional development after nursing school, where the participant was currently employed, and which settings and positions they were employed in. ${ }^{[12,17]}$ 2) Which nursing research-related tasks the MSN graduates were currently utilizing and improving. ${ }^{[17,24]} 3$ ) Improvements in the MSN graduates' nursing research knowledge. ${ }^{[17]}$ 4) The MSN graduates' current participation in research projects in clinical practice. ${ }^{[24,26]}$

5) The time spent by MSN graduates on nursing researchrelated tasks per week. ${ }^{[17]}$

\subsection{Data collection}

We used the online survey software "SurveyMonkey $§$ " (https://da.surveymonkey.com/) as an electronic data collection device through which the questionnaires were sent to the participating MSN graduates by e-mail. To describe and compare the development of the MSN graduates' utilization of nursing research-related tasks and knowledge in daily clinical practice, the questionnaires were sent to them at six months and twelve months after graduation. The class graduating in the summer of 2016 received and completed the questionnaire in the winter of 2016 (six months after graduation) and in the summer of 2017 (12 months afer graduation). The class graduating in the summer of 2017 received and completed the questionnaire in the winter of 2017 (six months after graduation) and in the summer of 2018 (12 months after graduation). Two gentle reminders to complete the questionnaire were sent to the participants in all four data collection rounds.

\subsection{Data analysis}

Data were analyzed using descriptive statistics and the results are presented as numbers and percentages. All statistics were performed using STATA software (12.0). We compared the MSN graduates' research utilization at six months and twelve months after graduation by examining the difference in percentages in the two periods.

\subsection{Ethical considerations}

The study was approved by the Danish Data Protection Agency (AU-case no.: 62908; unique AU-id: 310). The graduates were informed in writing prior to their participation about their legal and ethical rights. Consent to participate was considered as having been given when the graduates completed the questionnaire at six months after graduation.

\section{ReSUlts}

A total of $\mathrm{N}=112$ MSN graduates (2016: $\mathrm{N}=60 ; 2017$ : $\mathrm{N}=52$ ) were invited to participate. Of these, 65 graduates accepted, giving a response rate of $58.0 \%$ (see Table 1 ).

Table 1. Description of the participants

\begin{tabular}{lllll}
\hline & $\begin{array}{l}\text { Invited graduates } \\
\text { N }\end{array}$ & $\begin{array}{l}\text { Participants accepted } \\
\text { N (\%) }\end{array}$ & $\begin{array}{l}\text { Data collection six months } \\
\text { after graduation N (\%) }\end{array}$ & $\begin{array}{l}\text { Data collection twelve months } \\
\text { after graduation N (\%) }\end{array}$ \\
\hline Class of 2016 & 60 & $38(63.3 \%)$ & $31(81.6 \%)$ & $28(73.7 \%)$ \\
Class of 2017 & 52 & $27(51.9 \%)$ & $25(92.6 \%)$ & $21(77.7 \%)$ \\
Total sample & 112 & $65(58.0 \%)$ & $56(86.2 \%)$ & $49(75.4 \%)$ \\
\hline
\end{tabular}

A total of $\mathrm{N}=65(58.0 \%) \mathrm{MSN}$ graduates out of the $\mathrm{N}=112$, who agreed to participate, $\mathrm{N}=56(86.2 \%)$ graduates, completed the questionnaire at six months and $\mathrm{N}=49(75.4 \%)$ graduates at twelve months after graduation (see Table 1).

\subsection{Characteristics of the participating MSN graduates}

Demographic characteristics of the MSN graduates were collected during the first round of questionnaires at six months after graduation $(\mathrm{N}=56)$ ( see Table 2$)$.

The age distribution among the $56 \mathrm{MSN}$ graduates was greatest at 31-35 years of age $(\mathrm{N}=17(30.4 \%))$ and $36-40$ years $(\mathrm{N}=16(28.6 \%))$. The youngest MSN graduates were in the age range $25-30$ years $(17.9 \%)$, whereas the oldest group, greater than 56 years, contained just one (1.8\%) graduate (see Table 2).
The majority of the MSN graduates $(\mathrm{N}=26(46.4 \%))$ had qualified as nurses in the previous 5-9 years. Four MSN graduates had qualified 0-4 years previously (7.1\%) and 12 (21.3\%) MSN graduates had qualified more than 15 years previously (see Table 2).

The distribution of the number of working years in clinical practice among the MSN graduates showed that $20 \mathrm{MSN}$ graduates had worked from zero to 4 years $(35.7 \%)$ in clinical practice and $20(35.7 \%)$ had worked from 5 to 9 years. Only a single participant $(1.8 \%)$ had been working $\geq 25$ years in clinical practice (see Table 2).

The MSN graduates were asked if they had continued their professional development after nursing school. $\mathrm{N}=33$ (58.9\%) said "no" and $\mathrm{N}=23(41.1 \%)$ said "yes". The majority of MSN graduates who confirmed having continued 
their professional development after nursing school had completed parts of a bachelor's degree $(\mathrm{N}=15$ [65.2\%]). Of the remaining $\mathrm{N}=8$ participants, $\mathrm{N}=2(8.7 \%) \mathrm{MSN}$ graduates had completed a Master of Arts (MA) degree, $\mathrm{N}=2(8.7 \%)$ had completed a Master of Science (MSc) degree (8.7\%), and $\mathrm{N}=3(13.0 \%)$ had completed a bachelor's degree (see Table 2).

Table 2. Characteristics of the MSN graduates $(\mathrm{N}=56)$ at six months after graduation

\begin{tabular}{|c|c|}
\hline Variable & $\mathrm{N}=56(\%)$ \\
\hline \multicolumn{2}{|l|}{ Age (years) } \\
\hline $25-30$ & $10(17.9 \%)$ \\
\hline $31-35$ & $17(30.4 \%)$ \\
\hline $36-40$ & $16(28.6 \%)$ \\
\hline $41-45$ & $4(7.1 \%)$ \\
\hline $46-50$ & $1(1.8 \%)$ \\
\hline $51-55$ & $7(12.5 \%)$ \\
\hline$>56$ & $1(1.8 \%)$ \\
\hline No. of years qualified as a nurse & $\mathrm{N}=56$ \\
\hline $0-4$ & $4(7.1 \%)$ \\
\hline $5-9$ & $26(46.4 \%)$ \\
\hline $10-14$ & $14(25.0 \%)$ \\
\hline $15-19$ & $4(7.1 \%)$ \\
\hline $20-24$ & $4(7.1 \%)$ \\
\hline$>25$ & $4(7.1 \%)$ \\
\hline No. of years in clinical practice & $\mathrm{N}=56$ \\
\hline $0-4$ & $20(35.7 \%)$ \\
\hline $5-9$ & $20(35.7 \%)$ \\
\hline $10-14$ & $6(10.7 \%)$ \\
\hline $15-19$ & $3(5.4 \%)$ \\
\hline $20-24$ & $6(10.7 \%)$ \\
\hline$\geq 25$ & $1(1.8 \%)$ \\
\hline Continuing professional development after nursing school & $\mathrm{N}=56$ \\
\hline No & $33(58.9 \%)$ \\
\hline Yes: & $23(41.1 \%)$ \\
\hline Bachelor's degree & $3(13.0 \%)$ \\
\hline Parts of a bachelor's degree & $15(65.2 \%)$ \\
\hline Master of Arts (MA) degree & $2(8.7 \%)$ \\
\hline Parts of a Master of Arts (MA) degree & $0(0.0 \%)$ \\
\hline Master of Science (MSc) degree & $2(8.7 \%)$ \\
\hline Parts of a Master of Science (MSc) Degree & $1(4.3 \%)$ \\
\hline
\end{tabular}

Almost all of the MSN graduates were in employment after graduation (see Table 3).

$\mathrm{N}=52(92.9 \%)$ of the 56 graduates who participated during our first data collection were in employment after six months. Of the $\mathrm{N}=49$ graduates who participated in our second data collection, $\mathrm{N}=47$ graduates $(95.9 \%)$ were in employment after 12 months (see Table 3).

The employment settings with the greatest rise from the six to 12 months were the medical hospital departments, in which the MSN graduates' employment increased from $33.3 \%$ to $45.5 \%$ (+12.2\%), and the surgical hospital departments, in which their employment increased from $18.8 \%$ to $27.3(+8.5 \%)$. The employment settings with the biggest decrease from six to 12 months were employment in private institutions, which decreased from $22.9 \%$ to $3.0 \%$ (-19.9\%), in home care from $12.5 \%$ to $3.0 \%(-9.5 \%)$, in nursing homes from $6.3 \%$ to $3.0 \%(-3.3 \%)$, and in psychiatric departments which decreased from $6.3 \%$ to $3.0 \%(-3.3 \%$ ) (see Table 3 ).

The greatest difference regarding increases among positions in which the MSN graduates were employed at six and 12 months after graduation was clinical development nurse: $15.2 \%$ to $22.2 \%(+7.0 \%)$. A small increase was detected in positions as clinical educational nurses from $6.1 \%$ to $7.4 \%(+1.3 \%)$, clinical nurse specialist from $21.2 \%$ to $22.2 \%$ $(+1.0 \%)$, and charge nurse from $3.0 \%$ to $3.7 \%(+0.7 \%)$. The biggest differences regarding decrease in employment positions of the MSN graduates were positions as registered nurses, which decreased from $33.3 \%$ to $22.2 \%(-11.1 \%)$ and research nurses from $9.1 \%$ to $7.4 \%(-1.7 \%$ ) (see Table 3 ).

The MSN graduates' workload also changed between six and 12 months, where full-time employment increased from $73.1 \%$ to $78.7 \%(+5.6 \%)$ and part-timea employment decreased in total from $26.9 \%$ (6 months) to $21.3 \%$ (12 months) a decrease of $5.6 \%$ (see Table 3 ).

\subsection{Changes in the MSN graduates' utilization of nurs- ing research-related tasks and knowledge}

An improvement was detected from six to 12 months after graduation in the majority of items concerning the MSN graduates' utilization of nursing research-related tasks (see Table 4).

An increase was found in 10 items: using qualitative methods and analysis $(+19.9 \%)$, writing professional papers $(+15.8 \%)$, developing posters $(+15.4 \%)$, performing projects from own ideas $(+15.3 \%)$, getting ideas for new projects $(+14.8 \%)$, understand and evaluate Danish $(+13.8 \%)$ and English $(+8.7 \%)$ research papers, using statistical analysis $(+10.9 \%)$, searching for literature in databases $(+7.4 \%)$, and developing clinical guidelines $(+0.5 \%)$ (see Table 4$)$.

A decrease in utilization of research-related tasks from six to 12 months was found in conducting presentations using power point $(-5.6 \%)$, designing projects from own ideas $(-3.9 \%)$, writing scientific papers $(-2.1 \%)$, and project management (-1.0\%) (see Table 4$)$.

Improvements in the MSN graduates' nursing researchrelated tasks were detected from six to 12 months after graduation in 14 of the 15 items, with a difference from $+1.1 \%$ to $+15.8 \%$ (mean $9.2 \%$ ). Only one item, writing scientific pa- 
pers, had decreased, from $33.9 \%$ six months after graduation to $30.6 \% 12$ months after graduation $(-3.3 \%)$ in the MSN graduates' ongoing improvement of nursing research-related tasks (see Table 4).

Besides improving nursing research-related tasks, the MSN graduates also expressed an increased knowledge of research (see Table 5).

An increase in development of research knowledge was detected from six to 12 months in knowledge on qualitative analysis $(+14.0 \%)$, theory of science $(+9.7 \%)$, qualitative methods $(+5.1 \%)$, and statistical analysis $(+3.1 \%)$ (see Table 5).

Table 3. Development in MSN graduates' employment, positions and working hours

\begin{tabular}{|c|c|c|c|}
\hline & 6 months after graduation & 12 months after graduation & Difference $(-/+\%)$ \\
\hline Currently employed & $\mathrm{N}=56(\%)$ & $\mathrm{N}=49(\%)$ & \\
\hline Yes & 52 (92.9\%) & 47 (95.9\%) & +3.0 \\
\hline No & $3(5.4 \%)$ & $2(4.1 \%)$ & -1.3 \\
\hline Currently employed in (setting) & $\mathrm{N}=48(\%)$ & $\mathrm{N}=33(\%)$ & \\
\hline Home care & $6(12.5 \%)$ & $1(3.0 \%)$ & $-9.5 \%$ \\
\hline Nursing home & $3(6.3 \%)$ & $1(3.0 \%)$ & $-3.3 \%$ \\
\hline Acute/internal medicine & $4(8.3 \%)$ & $2(6.1 \%)$ & $-2.2 \%$ \\
\hline Psychiatric department & $3(6.3 \%)$ & $1(3.0 \%)$ & $-3.3 \%$ \\
\hline Medical hospital department & $16(33.3 \%)$ & $15(45.5 \%)$ & $+12.2 \%$ \\
\hline Surgical hospital department & $9(18.8 \%)$ & $9(27.3 \%)$ & $+8.5 \%$ \\
\hline Nursing education (university college) & $5(10.4 \%)$ & $3(9.1 \%)$ & $-1.3 \%$ \\
\hline Licensed advanced nursing Education & $1(2.1 \%)$ & $0(0.0 \%)$ & $-2.1 \%$ \\
\hline University & $0(0.0 \%)$ & $0(0.0 \%)$ & $0 \%$ \\
\hline Private institutions & $11(22.9 \%)$ & $1(3.0 \%)$ & $-19.9 \%$ \\
\hline Other & $0(0.0 \%)$ & $0(0.0 \%)$ & $0 \%$ \\
\hline Currently employed as (position) & $\mathrm{N}=33(\%)$ & $\mathrm{N}=27(\%)$ & \\
\hline Clinical nurse manager & $0(0.0 \%)$ & $0(0.0 \%)$ & $0 \%$ \\
\hline Charge nurse & $1(3.0 \%)$ & $1(3.7 \%)$ & $+0.7 \%$ \\
\hline Clinical nurse specialist & $7(21.2 \%)$ & $6(22.2 \%)$ & $+1.0 \%$ \\
\hline Clinical development nurse & $5(15.2 \%)$ & $6(22.2 \%)$ & $+7.0 \%$ \\
\hline Clinical educational nurse & $2(6.1 \%)$ & $2(7.4 \%)$ & $+1.3 \%$ \\
\hline Staff nurse & $11(33.3 \%)$ & $6(22.2 \%)$ & $-11.1 \%$ \\
\hline Research nurse & $3(9.1 \%)$ & $2(7.4 \%)$ & $-1.7 \%$ \\
\hline Teaching & $5(15.2 \%)$ & $4(14.8 \%)$ & $-0.4 \%$ \\
\hline Working hours (per week) & $\mathrm{N}=52(\%)$ & $\mathrm{N}=47(\%)$ & \\
\hline Full-time (37 hours per week) & 38 (73.1\%) & 37 (78.7\%) & $+5.6 \%$ \\
\hline Part-time* (30-35 hours per week) & $10(19.2 \%)$ & $6(12.8 \%)$ & $-6.4 \%$ \\
\hline Part-time $^{\dagger}$ (< 29 hours per week) & $4(7.7 \%)$ & $4(8.5 \%)$ & +0.8 \\
\hline
\end{tabular}

Note. ${ }^{*}: 30-35$ hours per week; ${ }^{\dagger}:<29$ hours per week

However, the MSN graduates were less concerned about knowledge of design, which decreased by $-1.5 \%$, and quantitative methods, which decreased by $-0.3 \%$, from six to 12 months after graduation (see Table 5).

The results showed a tendency in the MSN graduates' participation in research practice to decrease over time (see Table 6). At six months after graduation, $\mathrm{N}=29$ (51.8\%) MSN graduates replied "No" when asked if they were currently participating in research projects in clinical practice, whereas, after 12 months, $\mathrm{N}=30(61.2 \%)$ of the graduates replied "No", giving an increase of $+9.4 \%$ in zero participation (see Table 6).

While 15 (26.8\%) MSN graduates confirmed their participation in research projects at six months after graduation, the number decreased to $\mathrm{N}=12(24.4 \%)$ at 12 months, giving a decrease of $-2.6 \%$ over time. The MSN graduates were 
asked whether they were participating in planning, executing and/or presenting an accomplished project. A decrease was detected over time in developing a project from $26.8 \%$ to $20.4 \%(-6.4 \%)$ however, an increase was found in the numbers of MSN graduates participating in the execution of a project from $21.4 \%$ to $24.4 \%(+3.0 \%)$ and in presenting an accomplished project from $19.6 \%$ to $20.4 \%$ (+0.8\%) (see Table 6).

\subsection{Time spent on nursing research-related tasks}

The results showed a time range from zero to greater than 20 hours per week spent on nursing research-related tasks (see Table 7).

Table 4. The MSN graduates utilization and improvement of nursing research-related tasks

\begin{tabular}{|c|c|c|c|c|c|c|}
\hline & \multicolumn{3}{|c|}{ Utilization of research-related tasks } & \multicolumn{3}{|c|}{ Improvement of research-related tasks } \\
\hline & $\begin{array}{l}6 \text { months after } \\
\text { graduation } \\
\mathrm{N}=56(\%)\end{array}$ & $\begin{array}{l}12 \text { months after } \\
\text { graduation } \\
\mathrm{N}=49(\%)\end{array}$ & $\begin{array}{l}\text { Difference } \\
(-/+\%)\end{array}$ & $\begin{array}{l}6 \text { months after } \\
\text { graduation } \\
\mathrm{N}=56(\%)\end{array}$ & $\begin{array}{l}12 \text { months after } \\
\text { graduation } \\
\mathrm{N}=49(\%)\end{array}$ & $\begin{array}{l}\text { Difference } \\
(-/+\%)\end{array}$ \\
\hline $\begin{array}{l}\text { Getting ideas for new } \\
\text { projects }\end{array}$ & $18(32.1 \%)$ & $23(46.9 \%)$ & $+14.8 \%$ & $23(41.1 \%)$ & $22(44.9 \%)$ & $+3.8 \%$ \\
\hline $\begin{array}{l}\text { Designing projects from } \\
\text { own ideas }\end{array}$ & $17(30.4 \%)$ & $13(26.5 \%)$ & $-3.9 \%$ & $12(21.4 \%)$ & $11(22.5 \%)$ & $+1.1 \%$ \\
\hline $\begin{array}{l}\text { Performing projects from } \\
\text { own ideas }\end{array}$ & $12(21.4 \%)$ & $18(36.7 \%)$ & $+15.3 \%$ & $11(19.6 \%)$ & $13(26.5 \%)$ & $+6.9 \%$ \\
\hline $\begin{array}{l}\text { Using qualitative } \\
\text { methods and analysis }\end{array}$ & $14(25.0 \%)$ & $22(44.9 \%)$ & $+19.9 \%$ & $14(25.0 \%)$ & $20(40.8 \%)$ & $+15.8 \%$ \\
\hline Using statistical analysis & $3(5.4 \%)$ & $8(16.3 \%)$ & $+10.9 \%$ & 0 & $7(14.3 \%)$ & $+14.3 \%$ \\
\hline $\begin{array}{l}\text { Searching for literature in } \\
\text { databases (PubMed, } \\
\text { CINAHL mm) }\end{array}$ & $21(37.5 \%)$ & $22(44.9 \%)$ & $+7.4 \%$ & $15(26.8 \%)$ & $18(36.7 \%)$ & $+9.9 \%$ \\
\hline $\begin{array}{l}\text { Can understand and } \\
\text { evaluate Danish research } \\
\text { papers }\end{array}$ & $14(25.0 \%)$ & $19(38.8 \%)$ & $+13.8 \%$ & $13(23.2 \%)$ & $18(36.7 \%)$ & $+13.5 \%$ \\
\hline $\begin{array}{l}\text { Can understand and } \\
\text { evaluate English research } \\
\text { papers }\end{array}$ & $18(32.1 \%)$ & $20(40.8 \%)$ & $+8.7 \%$ & $15(26.8 \%)$ & $18(36.7 \%)$ & $+9.9 \%$ \\
\hline Developing posters & $4(7.1 \%)$ & $11(22.5 \%)$ & $+15.4 \%$ & $5(8.9 \%)$ & $9(18.4 \%)$ & $+9.5 \%$ \\
\hline $\begin{array}{l}\text { Conducting presentations } \\
\text { using PowerPoint }\end{array}$ & $26(46.4 \%)$ & $20(40.8 \%)$ & $-5.6 \%$ & $16(28.6 \%)$ & $20(40.8 \%)$ & $+12.2 \%$ \\
\hline $\begin{array}{l}\text { Writing professional } \\
\text { papers }\end{array}$ & $6(10.7 \%)$ & $13(26.5 \%)$ & $+15.8 \%$ & $6(10.7 \%)$ & $12(24.5 \%)$ & $+13.8 \%$ \\
\hline Writing scientific papers & $16(28.6 \%)$ & $13(26.5 \%)$ & $-2.1 \%$ & 19 (33.9\%) & 15 (30.6\%) & $-3.3 \%$ \\
\hline $\begin{array}{l}\text { Applying for research } \\
\text { funding }\end{array}$ & $8(14.3 \%)$ & $7(14.3 \%)$ & $0 \%$ & 5 (8.9\%) & $9(18.4 \%)$ & $+9.5 \%$ \\
\hline Project management & 12 (21.4\%) & $10(20.4 \%)$ & $-1.0 \%$ & $6(10.7 \%)$ & $9(18.4 \%)$ & $+7.7 \%$ \\
\hline $\begin{array}{l}\text { Developing clinical } \\
\text { guidelines }\end{array}$ & $10(17.9 \%)$ & $9(18.4 \%)$ & $+0.5 \%$ & $6(10.7 \%)$ & $6(12.2 \%)$ & $+1.5 \%$ \\
\hline
\end{tabular}

Table 5. The MSN graduates' improvements in nursing research knowledge

\begin{tabular}{llll}
\hline & After $\mathbf{6}$ months N = 56 (\%) & After 12 months N = 49 (\%) & Difference (-/+ \%) \\
\hline Designs & $18(32.1 \%)$ & $15(30.6 \%)$ & $-1.5 \%$ \\
Theory of science & $6(10.7 \%)$ & $10(20.4 \%)$ & $+9.7 \%$ \\
Qualitative methods & $20(35.7 \%)$ & $20(40.8 \%)$ & $+5.1 \%$ \\
Qualitative analysis & $15(26.8 \%)$ & $20(40.8 \%)$ & $+14.0 \%$ \\
Quantitative methods & $7(12.5 \%)$ & $6(12.2 \%)$ & $-0.3 \%$ \\
Statistical analysis & $4(7.1 \%)$ & $5(10.2 \%)$ & $+3.1 \%$ \\
\hline
\end{tabular}


Table 6. The MSN graduates participation in research projects in clinical practice

\begin{tabular}{llll}
\hline & $\begin{array}{l}\mathbf{6} \text { months after } \\
\text { graduation } \mathbf{N}=\mathbf{5 6}(\mathbf{\%})\end{array}$ & $\begin{array}{l}\mathbf{1 2} \text { months after } \\
\text { graduation } \mathbf{N}=\mathbf{4 9} \text { (\%) }\end{array}$ & $\begin{array}{l}\text { Difference } \\
\mathbf{( - / +} \%)\end{array}$ \\
\hline No & $29(51.8 \%)$ & $30(61.2 \%)$ & $+9.4 \%$ \\
Yes & $15(26.8 \%)$ & $12(24.4 \%)$ & $-2.6 \%$ \\
I am participating in developing a project & $15(26.8 \%)$ & $10(20.4 \%)$ & $-6.4 \%$ \\
I am participating in executing a project & $12(21.4 \%)$ & $12(24.4 \%)$ & $+3.0 \%$ \\
I am participating in presenting an accomplished project & $11(19.6 \%)$ & $10(20.4 \%)$ & $+0.8 \%$ \\
\hline
\end{tabular}

Table 7. Time spent on nursing research-related tasks per week

\begin{tabular}{llll}
\hline $\begin{array}{l}\text { Hours spent on research per } \\
\text { week }\end{array}$ & $\begin{array}{l}\mathbf{6} \text { months after graduation } \\
\mathbf{N}=\mathbf{5 0}(\%)\end{array}$ & $\begin{array}{l}\mathbf{1 2} \text { months after graduation } \\
\mathbf{N}=\mathbf{4 1}(\mathbf{\%})\end{array}$ & $\begin{array}{l}\text { Difference } \\
\mathbf{( - / +} \%)\end{array}$ \\
\hline 0 hours & $11(28.9 \%)$ & $6(19.4 \%)$ & $-9.5 \%$ \\
$1-5$ hours & $16(32.0 \%)$ & $12(29.3 \%)$ & $-2.7 \%$ \\
$6-10$ hours & $10(20.0 \%)$ & $12(29.3 \%)$ & $+9.3 \%$ \\
$11-15$ hours & $4(6.0 \%)$ & $4(9.8 \%)$ & $+3.8 \%$ \\
$16-20$ hours & $6(12.0 \%)$ & $4(9.8 \%)$ & $-2.2 \%$ \\
$>20$ hours & $4(8.0 \%)$ & $3(7.3 \%)$ & $-0.7 \%$ \\
\hline
\end{tabular}

At six months after graduation the majority of MSN graduates $(\mathrm{N}=16 ; 32.0 \%)$ spent $1-5$ hours per week on nursing research-related tasks, and at 12 months after graduation the majority of graduates spent 1-5 hours $(29.3 \%)$ or 6-10 hours $(29.3 \%)$ per week on nursing research-related tasks (see Table 7).

From six to 12 months after graduation, a decrease was found in the number of MSN graduates spending zero hours per week on nursing research-related tasks (-9.5\%); similarly, there was a decrease in the number of MSN graduates spending only 1-5 hours per week on these tasks $(-2.7 \%)$. However, in the same period there were increases in the number of MSN graduates spending 6-10 hours per week (+9.3\%) and 11-15 hours per week $(+3.8 \%)$ on these tasks. A decrease was found in the number of MSN graduates spending 16-20 hours per week on nursing research-related tasks (-2.2\%) and in the number of MSN graduates spending more than 20 hours per week (-0.7\%) (see Table 7).

\section{Discussion}

The overall results of the longitudinal cohort study showed a positive impact on the MSN graduates' development of their utilization and improvement of nursing research-related tasks and knowledge in daily clinical practice 12 months after their academic education. The MSN graduates had developed their utilization of nursing research-related tasks from six to 12 months after graduation with an average of $+13.6 \%$ and developed their improvement of nursing research-related tasks with an average of $+9.2 \%$. The results further showed

Published by Sciedu Press an ongoing improvement from six to 12 months in designing projects from own ideas $(+1.1 \%)$, conducting presentations using PowerPoint $(+12.2 \%)$, applying for research funding $(+9.5 \%)$, and project management $(+7.7 \%)$. The positive development in the MSN graduates' use and improvement of their academic competencies and knowledge in clinical nursing practice could be caused by the natural flow in the research process due to the late level of activities, such as applying for funding, presenting projects and project management. The development shows an increase in the MSN graduates' research experience over time, which is a well-known phenomenon in hands-on research ${ }^{[20]}$ ). Several studies ${ }^{[27-29]}$ show healthcare researchers' development of research experience through self-evaluated increases in research experience over time, led by exposure and commitment to research programmes and engaging in research activities. The development of the MSN graduates' research utilization from six to 12 months can also be viewed in comparison with their statements in our qualitative study of their experiences of engaging in nursing research-related tasks in daily clinical practice six months after graduation. ${ }^{[30]}$ In the semi-structured interviews the MSN graduates described barriers concerning how they felt limited in participating and utilizing nursing research-related tasks due to restrictions with their nursing management, the hierarchy and culture among their nursing colleagues and the limited time due to restrictions in their employment positions. ${ }^{[30]}$ Some of these barriers could very well have been overcome and improved over the following six months, which was what we found in our present cohort study according to the MSN graduates' 
positions of employment.

The results showed a positive change in the MSN graduates' positions of employment from six to 12 months after their graduation. An increase was found in the MSN graduates' positions of employment covering research and development, such as clinical nurse specialist $+1.0 \%$, clinical educational nurse $+1.3 \%$ and clinical development nurse $+7.0 \%$, and a decrease of $-11.1 \%$ was found in registered nurse positions. The development could show that more MSN graduates are hired in clinical practice because of their academic competencies and knowledge, as opposed to being employed in positions where the tasks of a staff nurse are required. Research shows that even though MSN graduates are underutilized in their early career they tend to be promoted relatively quickly. ${ }^{[12]}$ Furthermore, the results could also indicate that the MSN graduates change their workplace according to where there are opportunities for them to use their academic skills in clinical nursing practice, which is related to the increase in their utilization of nursing research-related tasks and improvements in their research knowledge and skills. The qualitative study describing the MSN graduates' experiences after six months showed that nursing management prioritized patientcare tasks for the graduates, instead of providing time for them to perform nursing research-related tasks. ${ }^{[30]}$ However, our results after 12 months could indicate a change in nursing management's prioritization of the MSN graduates' utilization of academic competencies and knowledge in their daily work. In this context, our results showed an increase over time in the number of hours per week the MSN graduates spent on nursing research-related tasks. After 12 months an additional $9.3 \%$ of the MSN graduates spent 6-10 hours per week on nursing research-related tasks and an additional $3.8 \%$ spent $11-15$ hours per week on these tasks, compared with the percentages at six months after graduation. After 12 months one-third (26.9\%) of the MSN graduates spent more than 11 hours per week on nursing research-related tasks.

There is clearly a positive development in MSN graduates' utilization and improvement of nursing research-related tasks and knowledge in daily clinical practice. However, do these research practices have an effect on the patients and do they have an impact on nursing care? Or is it research just for the sake of research? A questionnaire study was conducted by Hardwick and Jordan ${ }^{[31]}$ to survey 60 nurses and midwives graduating from a bachelor's or master's programme about their perceptions on how their practice had changed as a result of the academic knowledge they had required during their education. The findings showed that the graduates could provide many examples of which academic and research skills they had required: However, even though most felt their clinical practice had changed due to their studies, no practical examples were given. ${ }^{[31]}$ Change management was also taught successfully to many of the graduates; however, no examples of change or of new knowledge for clinical gain were given and the graduates blamed the existing barriers of time and lack of encouragement. ${ }^{[31]}$ In a systematic review exploring whether there is evidence that MSN nursing education affects patient care, Cotterill-Walker ${ }^{[13]}$ found no evidence of this in the 15 included studies. The participants explained their constraints in terms of colleagues and managers limiting their abilities to apply knowledge to clinical practice, feeling powerless to implement knowledge into practice and experiencing frustration at being unable to move forward in clinical practice. ${ }^{[13]}$ Cotterill-Walker ${ }^{[13]}$ states that future research must focus on specific clinical outcomes in order to evaluate MSN graduates' competencies to improve patient care.

\section{Strengths and limitations}

In our cohort study we only included graduating nurses from the MSN programme at one Danish University. We could have chosen to include graduating MSN nurses from other Danish Universities; however, the academic programmes differ in both teaching and acquired skills, which would have meant our results were not comparable. The study results, however, are still generalizable to other countries and practice settings due to the comparability to the international literature on the subject. In our search for questionnaires for data collection no complete questionnaire was found that met our study aim. However, we developed a purposiveconstructed five-theme questionnaire based on four validated questionnaires, which allowed us to address the specific questions we needed to be answered. This study contains a high proportion of missing values, which could affect its internal and external validity. However, decreasing response rates and missing values are often seen when outcomes are measures over two or more points in time, which is not the case in this study.

\section{Conclusion}

The overall results of the longitudinal cohort study showed a positive impact on the MSN graduates' development of their utilization and improvement of nursing research-related tasks and knowledge in daily clinical practice, as an increase in research and developmental positions of employment, and as an increase in time spent on nursing research-related tasks per week 12 months after graduation. Our study and the literature shows that providing nurses with Master's level knowledge and skills can make a difference for them in clinical practice. However, knowledge is still required on how MSN graduates' academic qualifications can have an impact on nursing and patient care. Future research needs to 
focus on practical observations of how the MSN graduates use their academic knowledge and skills to improve patient care and must furthermore focus on specific outcomes and observable criteria, in order to evaluate the MSN graduates' performance.

\section{ACKNOWLEDGEMENTS}

We appreciate and would very much like to thank the MSN graduate nurses for being able to take time out of their busy schedule to participate with valuable knowledge for this study.

\section{CONFlicts OF InTEREST Disclosure}

The authors declare that there are no conflicts of interest.

\section{REFERENCES}

[1] Bianchi M, Bagnasco A, Bressan V, et al. A review of the role of nurse leadership in promoting and sustaining evidence-based practice. J Nurs Manag. 2018; 26: 918-932. PMid:30198088 https: //doi.org/10.1111/jonm.12638

[2] Eskes AM, Storm-Versloot MN, Vermeulen H, et al. Do stakeholders in wound care prefer evidence-based wound care products? A survey in the Netherlands. Int Wound J. 2012; 9(6): 624-632. PMid:22248355 https://doi.org/10.1111/j.1742-481X.20 $11.00926 . \mathrm{x}$

[3] Van Oostveen CJ, Goedhart NS, Francke AL, et al. Combining clinical practice and academic work in nursing: A qualitative study about perceived importance, facilitators and barriers regarding clinical academic careers for nurses in university hospitals. J Clin Nurs. 2017; 26(23-24): 4973-4984. PMid:28793367 https://doi .org/10.1 $111 /$ jocn. 13996

[4] Wangensteen S, Johansson IS, Björkström ME, et al. Research utilization and critical thinking among newly graduated nurses: predictors for research use. A quantitative cross-sectional study. J Clin Nurs. 2011; 20(17-18): 2436-2442. PMid:21689180 https: //doi.org/10.1111/j.1365-2702.2010.03629.x

[5] Aiken L, Sloane DM, Clarke S, et al. Importance of work environments on hospital outcomes in nine countries. Int J Qual Health Care. 2011; 23(4): 357-364. PMid:21561979 https://doi.org/10.1 093/intqhc/mzr022

[6] Aiken LH, Sloane DM, Bruyneel L, et al. Nurse staffing and education and hospital mortality in nine European countries: a retrospective observational study. The Lancet. 2014; 383(9931): 1789-1790. https ://doi.org/10.1016/S0140-6736(13)62631-8

[7] Harding KE, Porter J, Horne-Thompson A, et al. Not enough time or a low priority? Barriers to evidence-based practice for allied health clinicians. J Cont Educ Health Prof. 2014; 34(4): 224-231. PMid:25530292 https://doi .org/10.1002/chp. 21255

[8] Thompson DS, O'Leary K, Jensen E, et al. The relationship between busyness and research utilization: it is about time. J Clin Nurs. 2008; 17(4): 539-548. PMid:18205684 https://doi .org/10.1111/j . 1365-2702.2007.01981.x

[9] Loke JCF, Laurenson MC, Lee KW. Embracing a culture in conducting research requires more than nurses' enthusiasm. Nurse Educ Today. 2014; 34(1): 132-137. PMid:23031532 https://doi.org/ $10.1016 / j$.nedt .2012 .09 .006

[10] Brown CE, Ecoff L, Kim SC, et al. Multi-institutional study of barriers to research utilisation and evidence-based practice among hospital nurses. J Clin Nurs. 2010; 19(13-14): 1944-1951. PMid:20920021 https://doi.org/10.1111/j.1365-2702.2009.03184.x

[11] Breimaier HE, Halfens RJ, Lohrmann C. Nurses' wishes, knowledge, attitudes and perceived barriers on implementing research findings into practice among graduate nurses in Austria. J Clin Nurs. 2011;
20(11-12): 1744-1756. PMid:21362075 https ://doi.org/10.1 $111 / j .1365-2702.2010 .03491 . x$

[12] Drennan J. Professional and academic destination of masters in nursing graduates: A national survey. Nurse Educ Today. 2008; 28(6): 751-759. PMid:18242790 https ://doi.org/10.1016/j . nedt. 2007.12 .003

[13] Cotterill-Walker SM. Where is the evidence that master's level nursing education makes a difference to patient care? A literature review. Nurse Educ Today. 2012; 32(1): 57-64. PMid:21371793 https://doi.org/10.1016/j.nedt.2011.02.001

[14] Clark L, Casey D, Morris S. The value of Master's degrees for registered nurses. Brit J Nurs. 2015; 24(5): 16-20. PMid:25815824 https://doi.org/10.12968/bjon.2015.24.6.328

[15] Atkins M, Redley M. The assurance of standards at master's level: an empirical investigation. High Educ Quart. 1998; 52(4): 378-393. https://doi.org/10.1111/1468-2273.00106

[16] Severinsson E. Research supervision: supervisory style, reseachrelated tasks, importance and quality - part 1. J Nurs Manag. 2012; 20(2): 215-223. PMid:22380416 https://doi.org/10.1111/j. 1365-2834.2011.01361.x

[17] Akerjordet K, Lode K, Severinsson E. Clinical nurses' research capacity in a Norwegian university hospital: part 2. J Nurs Manag. 2012; 20(6): 824-832. PMid:22967300 https://doi.org/10.1 $111 / j .1365-2834.2012 .01473 . x$

[18] Watkins D. The influence of Masters education on the professional lives of British and German nurses and the further professionalization of nursing. J Adv Nurs. 2011; 67(12): 2605-2614. PMid:21615461 https://doi.org/10.1111/j.1365-2648.2011.05698.x

[19] Graue M, Rasmussen B, Iversen AS, et al. Learning transitions-a descriptive study of nurses' experiences during advanced level nursing education. BMC Nurs. 2015; 14: 30. PMid:25977642 https : //doi.org/10.1186/s12912-015-0080-z

[20] Zahran Z. Master's level education in Jordan: A qualitative study of key motivational factors and perceived impact on practice. Nurse Educ Today. 2013; 33(9): 1051-1056. PMid:22583814 https: //doi.org/10.1016/j.nedt.2012.04.007

[21] Polit DF, Beck CT. Nursing Research: Generating and Assessing Evidence for Nursing Practice (10th Edition). Wolthers Kluwer; 2018.

[22] Berthelsen C, Martinsen B, Vamosi M. Master of Science in Nursing students' expectations to participate in nursing research-related tasks in clinical practice after completing their education - A crosssectional survey. In review with JNEP.

[23] Funk SG, Champagne MT, Wiese RA, et al. Barriers: The barriers to research utilization scale. Appl Nurs Res. 1991; 4(1): 39-45. https://doi.org/10.1016/S0897-1897(05) 80052-7

[24] Berthelsen CB, Hølge-Hazelton B. Orthopaedic nurses' attitudes towards clinical nursing research - A cross-sectional survey. Int J 
Orthop Trauma Nurs. 2015; 19(2): 74-84. PMid:25846220 https : //doi.org/10.1016/j.ijotn.2014.10.004

[25] Jacobson AF, Warner AM, Fleming E, et al. Factors influencing nurses' participation in clinical research. Gastroenterol Nurs. 2008; 31(3): 198-208. PMid:18542021 https://doi.org/10.1097/01 .SGA.0000324112.63532.a2

[26] Parahoo K. Research utilization and research related activities of nurses in Northern Ireland. Int J Nurs Stud. 1998; 35(5): 283-291. https://doi.org/10.1016/S0020-7489(98)00041-8

[27] Schmidt DD, Webster E, Duncanson K. Building research experience: Impact of a novice researcher development program for rural health workers. Austral J Rural Health. 2019; 27(5): 392-397. PMid:31245898 https://doi .org/10.1111/ajr.12520

[28] Boyle SE, Seonaidh CC, Phyo KM, et al. The influence of early research experience in medical school on the decision to intercalate and future career in clinical academia: a questionnaire study. BMC Med Educ. 2017; 17: 245. PMid:29228999 https://doi.org/10 .1186/s12909-017-1066-1

[29] Gimpel N, Pagels P, Kindratt T. Community action research experience (CARE): training family physicians in community based participatory research. Educ Prim Care. 2017; 28(6): 334339. PMid:28245361 https://doi.org/10.1080/14739879.2 017.1295789

[30] Berthelsen C, Vamosi M, Martinsen B. Camouflaging nursing research-related tasks in clinical practice - Experiences of newlygraduated Masters of Science in Nursing. J Nurs Res Prac. 2020; 10(3): 42-50. https : //doi.org/10.5430/jnep.v10n3p42

[31] Hardwick S, Jordan S. The impact of part-time post-registration degrees on practice. J Adv Nurs. 2002; 38(5): 524-535. PMid:12028286 https://doi.org/10.1046/j.1365-2648.2002.02214.x 